\title{
The English Entertainment for the French Ambassadors in 1564
}

The Thynne family papers at Longleat House shed important new light on theatrical and musical performers and performances at the English court from late in the reign of Henry viII until that of Charles I. One letter in the eight volumes of correspondence is particularly enlightening in this regard because of the detail with which it describes the entertainment of the French ambassadors when they came to England in 1564 to conclude the Treaty of Troyes. This account of the reception of the embassy from France is found in a letter, dated 9 June of that year, from William Honing to Sir John Thynne. ${ }^{1}$ Although we have long known that Elizabeth's offices of the revels and the works produced masques and martial sports on this occasion, Honing's letter provides new information about the prominent role Sir Robert Dudley played in the shows, the creative contribution of Richard Edwards, master of the Children of the Chapel Royal, and the performance - the earliest that has come to light so far - of Thomas Churchyard, the indefatigable soldier, poet, patron-seeker, and author/performer/producer of Elizabethan court shows. My main aim in this paper is to describe and contextualize the theatrical devices produced for the French embassy in 1564, for they illustrate several important aspects of the art and politics of occasional, elite drama at the court of Elizabeth I. To this end some examination of another early Elizabethan entertainment for ambassadors from France, that celebrating the conclusion of the Treaty of Blois in 1572, is helpful. For this later reception we have no letter-writer's narrative of what occurred, but we do have one of the most detailed financial records of the expenses of the revels office in producing such a show. The different kinds of documentary sources of these two entertainments determine and condition the information they include, information which is as a result partial and sometimes ambiguous, contradictory, or opaque. Although we now have more information about these early Elizabethan entertainments, what we make of them as mediated 
by the epistolary report, the financial accounts, and other kinds of records remains to some extent provisional.

The letter from William Honing to Sir John Thynne is one of many records of musical and dramatic activity in the several collections of family papers at Longleat, those not only of the Thynnes but also of the Dudley, Devereux, and Seymour families. The Seymour papers, which have been more thoroughly investigated than the Thynne records, best suggest how rewarding these collections may be. In Patrons and Musicians of the English Renaissance, David C. Price found in the Seymour papers evidence of 'Mogul-like buying of instruments', ${ }^{2}$ patronage of Sir Edward Seymour's own troupe of minstrels, rewards to court musicians, payments to the players of other noblemen, and provisions for the musical education of his children. Although seventeenth-century records of patronage by Sir William Seymour and musical activity in his household are scarce, the few that do survive suggest that he continued 'the extraordinary musical traditions fostered by his grandfather and great grandfather, traditions which seem to have reached an apogee of literate and informed patronage in the early Jacobean period'. ${ }^{3}$ Price also culled from the family records of the Thynnes the names of eight different musicians hired to teach the children or to perform at one of the family's houses, ${ }^{4}$ but because Price limited himself mainly to the account books and to patronage of music within the household, he deliberately excluded the specifics of payments elsewhere to Robin Hood players in 1555, musicians at Christmas in 1570, a taborer in 1571, puppet players in 1578, a minstrel and waits in 1581, and an unidentified acting company in $1604 .^{5}$ The family collections at Longleat are rich with evidence of music and drama not only in Wiltshire but also, surprisingly, at court. ${ }^{6}$

A major change in Sir John Thynne's personal circumstances in the early 1550s may help us account for the inclusion of this material in his family papers. Thynne became at this time more dependant than ever before on letters from his contacts in London for the latest news from the court, the city, Scotland, Ireland, and continental Europe. His fortunes rose and fell with those of Sir Edward Seymour, ultimately duke of Somerset and lord protector, whose service Thynne entered in 1536, the year in which Seymour's prominence in the service of Henry viII began. In that year, the king married his third wife, Jane Seymour, the younger sister of Edward, who was created viscount Beauchamp on that occasion. Within the year, she gave birth to a son, Prince Edward, at whose baptism on 15 October 1537 Seymour had the privilege of carrying the little princess Elizabeth. A few days later, as part of 
the celebration of the birth and christening of the prince, Henry elevated Seymour further by making him earl of Hertford. A trusted councilor and a successful military leader, he remained a strong supporter of Henry vin's protestant regime; judging by policies that Seymour would later pursue, if he had any reservation about the king's religious reforms, it was that they did not go far enough. When Henry viII died in 1547 his ten-year-old son (and Seymour's nephew of course) acceded to the throne as King Edward vi. Despite the provision in Henry viII's will for conciliar government until Edward reached the age of eighteen, the executors of the will appointed Seymour lord protector of the realm and governor of the king's person, and the new king created him duke of Somerset. Edward Seymour, however, had reached the zenith of his power; he had been, as it were, promoted to his level of incompetence. In October 1549, as a result of a combination of factors - 'the disastrous and costly war with Scotland and France, opposition to his domestic reforms, growing factionalism among nobility and gentry opposed to his authoritarian leadership, and fear that his populist policies would lead to further disorder among the commons ${ }^{7}$ — he was deprived of all his offices and imprisoned in the Tower. Despite a pardon and the partial restoration of his power during the next two years, rival members of the council conspired together to indict him. Convicted not for treason but for another felony, Seymour was executed in January 1552.

His fall created a crisis for Sir John Thynne. Perhaps because of the influence of his uncle Sir William Thynne, a member of Henry vin's household, John Thynne had first secured a position in the household of Lord Vaux in 1535 and then went on to serve as Edward Seymour's steward from 1536 to 1552. While serving Seymour through his rise to power, Thynne developed profitable commercial interests in London, married into one of the most powerful families there (that of Richard Gresham, a lord mayor of London), and used his position at court and his increasing wealth in order to acquire and develop several estates in the provinces, 'mainly in the west and centering on the former Carthusian priory at Longleat, which he bought from Sir John Horsey in 1540'. ${ }^{8}$ Like many others associated with Seymour when he fell, Thynne also suffered: he was imprisoned twice, lost offices at court, and paid financial penalties, but he did escape with his life. Withdrawing to his estate at Longleat in Wiltshire, Thynne prudently retreated from public life throughout the reign of King Edward's Roman Catholic sister, Mary, who came to the throne in 1553 . When a protestant regime was restored with the accession of Queen Elizabeth in 1558, Thynne again played a role 
in national affairs, albeit a smaller one, as a member of parliament in 1559, 1563, 1571, and 1572 .

When Thynne withdrew to Longleat, he directed his energies to what would really be his life's work, the design and building of Longleat House, a project that would engage him until his death in 1580. As long as Thynne was an important figure in Seymour's household and Seymour was at the centre of power, Thynne did not need regular reports of news from the court; he was there, immersed in the flow of information, gossip, rumour, and news. ${ }^{9}$ Indeed his correspondence during this time of Seymour's ascendancy constituted a 'machine-gun cannonade of letters' 10 not to him, but from him, in London, directing the work of those building Longleat House and managing his country estates. But when Seymour and Thynne fell from power and the latter returned to Wiltshire, he needed agents in London to help him stay in touch with international politics, the state of affairs in Scotland and Ireland, and events at court. Thynne received scores of communiqués from various individuals who helped him conduct his business in the city and kept him abreast of the news there. To call these letters 'news letters' would be a misnomer, for the letters Thynne received in the mid-sixteenth century were informal in tone, personalized in references, uneven in the handwriting, and, so far as we know at present, sent to him alone rather than distributed to a group. They were, at best, precursors of the handwritten 'separates' commissioned by individuals or groups 'to whom the political and economic events of the day were matters of urgent importance', ${ }^{11}$ these 'separates' being late sixteenth-century forerunners of the earliest newspapers in England. Of theatrical activity at court, Thynne's correspondents reported on such things as the plans for the coronation pageants for Queen Mary, ${ }^{12}$ martial sports for King Philip II of Spain when he arrived to marry Queen Mary in 1554, ${ }^{13}$ arrangements for a projected meeting of Queen Elizabeth I and Mary Queen of Scots at Nottingham in 1562, the early success the new master of the revels Thomas Benger had with devices celebrating Lord Cobham's marriage, Benger's later imprisonment in the Tower for a masque of women with which he surprised the queen, and the preparation of a 'triumph' of courtiers for the entertainment of a French embassy in $1567 .{ }^{14}$

Among these letters from his London contacts is the one from William Honing describing Elizabeth I's reception and entertainment of the French ambassadors in June 1564. Honing and Sir John Thynne may have met in the mid 1530s, when Thynne entered the service of Seymour and Honing secured the position of sergeant of the acatry in the royal household. Their 
paths would certainly have crossed in the 1540s, given Honing's appointment as clerk of the privy council on 13 April $1543 .{ }^{15} \mathrm{He}$ held this office close to the centre of power throughout the ascendancy of Seymour, but when Seymour fell, Honing, like Thynne, came under suspicion and was 'deprived of his clerkship'. ${ }^{16}$ Fortunately for Honing, however, in the early 1540s he had also succeeded William Paget as one of the four clerks of the signet. ${ }^{17}$ He retained this office despite the demise of the lord protector and through the reign of Mary I, and in 1557 Honing, Nycasius Yetsweirt, John Clyff, and Francis Yaxley agreed to the terms for doing their work and sharing their fees as clerks of the signet. ${ }^{18}$ All these posts held by William Honing 'had the value of a permanent place at court, and the possibility of interaction with members of the privy council or the monarch'; ${ }^{19}$ in short, with respect to court news, he remained one of Sir John Thynne's associates who was 'in the know'. Presumably this William Honing was the same man who in 1543 shared land with William Taylor and Christopher Harbottle, haberdashers who supplied the revels office with garments and materials. ${ }^{20}$ Since revels office personnel were involved in designing and producing the shows for the French ambassadors in 1564, this connection to the revels might have provided Honing with access to the specific kinds of information needed to satisfy Sir John Thynne's interest in entertainments at court, especially those with international implications. The William Honing who served as a clerk of the signet died in 1569; perhaps it was his son and namesake who, benefiting from his father's contacts, became the clerk controller in the office of the tents and revels in $1584 .^{21}$

Honing's letter, dated 9 June 1564, one day after the two-day entertainment, is based on a retrospective account of the events, apparently that of an eye-witness. Having described the main performances at Richmond and Hampton Court, Honing continues rather awkwardly, attaching to the first part of the letter a summary of the earlier journey of the ambassadors from Dover to London. ${ }^{22}$ The queen had taken the normal steps to ensure that the embassy, led by the distinguished French nobleman Artus de Cossé, seigneur de Gonnor, would be honourably welcomed at Dover and escorted from there to London by her officials and many gentlemen of Kent. ${ }^{23}$ Honing confirms that her orders were followed, at least by leading noblemen of the province; ${ }^{24}$ he notes that the French visitors were received and entertained by Henry Norris; Sir Henry Neville, lord Abergavenny (with eighty attendants on horseback); Sir Anthony Browne, viscount Montague; Sir Edward Clinton, earl of Lincoln and lord admiral; and Matthew Parker, archbishop of 
Canterbury. The glimpses the ambassadors received of the English countryside, architecture, and social conditions were not without political significance. When they stayed at Bekesbourne, just southeast of Canterbury, with the archbishop on Friday, 2 June, his hospitality included several hours discussing the beliefs and practices of the reformed church of England, ecclesiastical governance, the dissolution of the monasteries, and the consequent redistribution of wealth. ${ }^{25}$ In a remarkable moment of candour during this stop, some of the French gentlemen noted how 'much more misery' there was in France than what 'was commonly known abroad with us'. ${ }^{26}$ Parker responded with some openness of his own, revealing to them some of his armoury 'whereby they did see that some preparation we had against their invasion, if it had been so purposed. And so some of them expressed, that if a bishop hath regard of such provision, belike other had a more care thereabout'. ${ }^{27}$ After two days at Greenwich, the French ambassadors travelled by water to London on Tuesday, 6 June, when seigneur de Gonnor met formally with Queen Elizabeth, seated in her state and listening to music, after which meeting Sir Robert Dudley provided a feast for the ambassador and some others, as Honing says, 'of the bettre sorte'.

The occasion for this French diplomatic mission and the festivities associated with it was the very qualified success, at best, of the bellicose protestant foreign policy pursued during the first years of Elizabeth I's reign. ${ }^{28}$ In April 1559 England ratified the Treaty of Cateau-Cambrésis in accordance with which England gave up the port of Calais to France in return for payment of 500,000 crowns. ${ }^{29}$ To ensure that the French honoured their part of the bargain, English forces led by Ambrose Dudley, earl of Warwick and master of the ordnance, occupied Le Havre from the fall of 1562 until July 1563, when an alliance of the French royal army and huguenot troops, temporarily setting aside their religious differences for patriotic purposes, ${ }^{30}$ forced the English to surrender the city. The huguenots may have had another reason for joining the siege of Le Havre: they had not received the direct military support that they hoped Warwick and the English forces would supply, for within two months of his arrival in Le Havre in 1562, 'Elizabeth ordered him not to give active military support to the French protestants'. ${ }^{31}$ Warwick and his company valiantly defended the town (he received a serious injury in the process) and surrendered to the leader of the French forces, Charles de Cossé, maréchal de Brissac, ${ }^{32}$ but only when an outbreak of the plague had decimated the garrison. Foregoing two-thirds of the compensation provided by the terms of Cateau-Cambrésis, Elizabeth accepted the 
loss of Calais and Le Havre by signing the Treaty of Troyes in April 1564. While this peace treaty was a setback for early Elizabethan foreign policy, it was nevertheless 'proclaimed with sound of trumpet, before her Majestie in her Castle of Windsor, there being present the French Ambassadors'. ${ }^{33}$ The queen rewarded Ambrose Dudley for his service with estates in the west midlands and election to the Order of the Garter. In June 1564, Elizabeth I and her court celebrated the peace treaty and fêted the French ambassadors with an entertainment that comprised an array of courtly devices.

Masques, we have known for many years, were one form of entertainment produced in celebration of this peace treaty. Sir Thomas Benger, master of the revels, mentioned them and related expenses in his 'estimate' of expenditures by the revels office between Christmas 1563 and Shrovetide 1564. He recorded few details, only the approximate total, $£ 87$ 9s $6 \mathrm{~d}$, for

... Translattinge new makinge of thre masks and other devisses Agaynst the french Embassitours cominge to Richmond wages or dieats of the officers and Tayllors payntars workinge vppon the Castle and other devisses \& mercers ffor Sarsnett and other stuf and Lynen drappars ffor canvas to couer yt with all and Silkwemen for ffrenge \& tassales to garnesh the old garments to make them seme fresh Agayne and other provicions \& necessaries. ${ }^{34}$

The exchequer of receipt also issued a warrant authorizing payment of $£ 123$ 6s $7 \mathrm{~d}$ to Lewes Stocket, surveyor of the works, 'for the charges of suche workes as were made against the comminge hither and in the time of the beinge here of Monsieur Gonnort of late Ambasador owte of ffraunce'. ${ }^{35}$ And the State Papers Foreign include a letter from the queen to her ambassadors in France which sheds light on another aspect of the entertainment. In it she specifies what martial sports formed part of the event; after dining with her at Richmond, the French ambassadors saw 'certain pastimes of running at the ring, hunting and killing three stags' and the next day, after a tour of Hampton Court and hunting there, they beheld 'the barriers and other pastimes in her hall'. ${ }^{36}$ While these documents establish the kinds of shows laid on for seigneur de Gonnor and his attendants, they provide no detail apart from the suggestive mention of 'the Castle' about the dramatic content of the 'pastimes', 'workes', 'masks and other devisses' prepared for the occasion. William Honing's letter to Sir John Thynne supplies much more of that information. 
Honing reports that at Richmond on Wednesday, 7 June, with Queen Elizabeth seated in a viewing gallery, who was as ever the observed of all observers on such occasions, ${ }^{37}$ 'the lord Robert' (Sir Robert Dudley, master of the queen's horse), Sir George Howard, 'mr Charles', and 'mr William', 38 who along with all of their footmen wore the green and white colours of the Tudors, entered the yard on horseback. A stag and hind were then released into the yard, which had been enclosed with toils, canvas screens or nets used to contain game, ensure the success of this hunt, and keep it in view of the audience. Dudley and his fellows with the help of a pack of dogs then chased the deer about the space, cornered them in front of the queen's gallery, and there slew them. Presumably the show ended with a ceremonial presentation of the slaughtered animals to the monarch so as to dramatize the devotion of Dudley and his company to the service of their queen.

While the display hunting was proceeding, three other groups of tilters gathered near the field. One was led by Robert Dudley's brother, Ambrose, earl of Warwick, who had surrendered Le Havre to the French forces earlier in the year. He and his followers were 'trymmed in whyte $\&$ blake Rutter facion', their colours being those of Queen Elizabeth herself. This group carried handguns that they discharged after their entry. The second troop was led by the lord admiral, Edward Fiennes de Clinton, earl of Lincoln, attired 'in blew taffeta albanyes facion'. The last set of knights, led by Sir Walter Devereux, viscount Hereford, were costumed 'lyke woodmen dressed in yvey', that is, like the wodemen, wild men, or green men found in Celtic myths, English folklore, chivalric romances, and entertainments at court. Obviously aligned with the forces of nature, these 'woodmen' embodied on this occasion 'the idea of male protectiveness in a female court', ${ }^{39}$ for they came to the lists not to fight against Elizabeth's other knights (as eight wild men had attacked eight English knights as part of the festivities on Twelfth Night 1515) but to participate with them in the martial sports. ${ }^{40}$ After their ceremonious entry into the lists, the noblemen spent an hour or so running at the ring. Usually such martial sports served to demonstrate the combatants' skill in feats of arms, but in this case, Honing had to admit, there was 'moch myssinge', which he tried to excuse by noting that the horses might not have been the best or the sun might have been in the participants' eyes. On this afternoon the jousters gave the French visitors little to admire or, if these martial sports were to be taken as signs of real military strength (like the cache of weapons that archbishop Parker showed the French visitors), little to 
fear. ${ }^{41}$ When these courtly pastimes were done, the ambassadors enjoyed a feast at which songs and instrumental music served as entertainment.

The following day, 8 June, Hampton Court became the site for the entertainment of the ambassadors. After hunting in nearby parks de Gonnor and his company returned to the great hall of Hampton Court for dinner. In the lower end of the hall stood two pageants, one a castle called the 'Chasteau amyable' (the Castle of Love) and the other an 'herber grene named Vergier doloreuse' (the Orchard, or Arbour, of Sorrow). Both the English and French danced for a while, and then a herald ('one churchyard'), dressed in crimson armour and carrying an image of a heart strained between two hands, entered from the latter pageant and gave a speech lamenting the cruelty of the ladies of the castle, who refused to accept the love offered them. When he concluded that these opponents of love ought to be assailed, the knights on the arbour pageant, obviously the unhappy victims of unrequited love, descended from the pageant and prepared to besiege the castle. ${ }^{42}$ Before they could do so, the ladies emerged from it and gathered by the lower end of the barrier that had been set up in the hall. Then their herald, Richard Edwards, master of the Children of the Chapel Royal, defended them by arguing 'what spyte yt shuld be to love without lykinge'. Cued by Edwards's speech, out of the castle came Sir Robert Dudley, his brother Ambrose, Sir George Howard, and other knights. Before the combat began, the earl of Sussex presented the queen with a book containing the names of all the participants, who then fought at the barriers with staff and sword in defence of the ladies of the castle. ${ }^{43}$ With the arrival of a masque of men, the barriers came to an end. These masquers were led in by a herald in a costume trimmed with roses and fleurs-de-lis, who declared that arms were to cease and give way to peace. The first of the masquers carried a lily and olive branches, with the word 'vnitas' written on the flower. The men then danced for a while and with their exit brought to an end the chief show laid on for the ambassadors from France.

The link between the fictional resolution and the historical event that occasioned the show makes the first political point of this entertainment quite clear. The flowers of England and France adorning the herald's costume, the call for combat to cease, the symbolic stage properties (the lily and the olive branch), the sign explicitly announcing unity, and the dancing, all symbolically affirmed the achievement of harmony, not only between the characters within the show but also between England and France. Celebrating as it did the end of conflict and the achievement of peace, the theatrical 
device affirmed to the French ambassadors that England endorsed the peace treaty negotiated at Troyes. In the resolution of the action and the visual features of the performance, the entertainment deployed 'a powerful international rhetoric of performance and spectacle', a rhetoric also used at this time in court performances in Scotland and France as 'an instrument, however minor, of prestige, of diplomacy, of politics and sometimes of government itself. ${ }^{44}$

The entertainment for French ambassadors that occurred in 1572 probably functioned in a similar way and to the same end. That embassy, led by Henri duc de Montmorency, came to England to ratify the Treaty of Blois and begin negotiations for a marriage alliance between Queen Elizabeth and François duc d'Alençon. The treaty represented a new departure in Elizabethan foreign policy by pursuing an alliance with a longstanding foe in order to protect both countries from the potential aggression of Spain. We do not know for certain, however, how the show on this occasion ended because no extant record lays out the story-line of the device. Instead we have the financial accounts of the revels office which include a long list of discrete payments for sets (movable pageants of Mount Parnassus, a castle of Lady Peace, and a prison) and for the costumes of certain characters (Lady Peace, Argus, Discord, Apollo and the Nine Muses). If this entertainment was an adaptation for the current occasion of the pageants first prepared for the projected meeting of Elizabeth I and Mary Queen of Scots at Nottingham in 1562, ${ }^{45}$ then the plot probably included a threat to Lady Peace by Discord that plausibly led to the tourney between Essex's and Rutland's knights. Discord, defeated in some way through this exhibition of martial skill, was probably led off by the chain of gold leather to the prison, guarded by the many watchful eyes of Argus. Given the successful defence of Lady Peace, the desired harmony would then have been celebrated in song by the Nine Muses and in the dances of the French lords and English ladies. Another contemporary document suggests that another image of harmony was used on this occasion. A brief report of the show notes the part played by 'a faire damsell' who 'presented certaine speeches in the ffrench tonge vnto her Majestie.' ${ }^{46}$ Different languages were clearly no impediment to harmony between these nations. If this narrative of the 1572 show gleaned largely from the revels account is plausible, then we can see both this entertainment of the French ambassadors and that of 1564 as shows that were, to use Sarah Carpenter's phrase, theatrical devices 'performing diplomacy' — and that of the moment. ${ }^{47}$ 
The second political dimension of the 1564 entertainment is only slightly less obvious than the first. Given the anxiety in the air at that time about the succession, anxiety that Elizabeth could alleviate by taking a husband and begetting a son, some who witnessed the shows for the French visitors would undoubtedly have seen the prominent role Sir Robert Dudley played as part of his courtship of Elizabeth and a sign of her fondness for her favourite. The queen may have already decided that her only husband would be the nation, but Dudley still had hopes that he might win her hand in marriage. He had expressed his desire in a theatrical form when he played the part of Prince Pallaphilos, a second Perseus and as such a disciple of Pallas, at the Inner Temple during the Christmas season 1561/2. The occasion and the main features of that show for its mock court were remarkably similar to those of the 1564 entertainment of the ambassadors at Queen Elizabeth's court. After settling a real dispute between the Inner and the Middle Temples (as France and England had settled theirs), Dudley as Pallaphilos received fictional foreign ambassadors from the other inns of court (as Elizabeth received those from France) and entertained them with tilt, tourney, masque, and other ceremonies of knighthood. The masque that concluded the celebration, which portrayed his hopes as if they were already realized, was, as Susan Doran states, 'a wooing allegory in which Lady Beauty (signifying Elizabeth) was successfully courted by Desire (Dudley), and wed in the Temple of Pallas after the goddess had expressed her approval of the match', which was then celebrated with a dance. ${ }^{48}$ The entertainment of the French ambassadors in 1564 offered another opportunity for him 'to define his relationship with the sovereign in public by performing it before her ${ }^{2} 9$ and to represent himself as the man best suited to be her consort. Donning the livery of Queen Elizabeth and taking a leadership role in various aspects of the reception, he demonstrated his loving readiness to serve her, his skill in knightly exercises, and his willingness to provide generous hospitality to her guests. And she was not the only person in the audience to whom this exhibition of gentlemanly accomplishments was directed. ${ }^{50}$ If he could impress foreign ambassadors and other noblemen at court that he was the best candidate to marry the queen, then he might out-manoeuvre those who for political or dynastic reasons preferred one of his rivals. ${ }^{51}$ The prominence of Sir Robert Dudley in the entertainments of the French ambassadors was a sign of Queen Elizabeth's favour towards him and a step in his courtship of her.

Thirdly, the various artistic elements of the shows and ceremonies for the entertainment of the French ambassadors in 1564 constitute yet another 
political dimension of the event. Every feature of the entertainment, from the presence of English noblemen to greet the noble Frenchmen upon their arrival in Dover to the presentation of rich gifts for them to take back to France, made manifest the magnificence of Queen Elizabeth and her court. In this use of spectacle for diplomatic purposes, the Elizabethan entertainments for foreign embassies hark back to the practice of her grandfather Henry viI. He attempted to ennoble and secure the Tudor regime by negotiating marriages for his children Prince Arthur, Princess Margaret, and Princess Mary, marriages that sealed treaties with Spain, Scotland, and France respectively. He also systematically adopted, as Gordon Kipling observes, 'forms of poetry, drama, chivalry, architecture, painting, and scholarship ... imitated directly from Burgundian models ${ }^{52}$ in order to establish that his household was as royal as any in Europe. Specifically with respect to theatrical devices for the royal wedding of Prince Arthur and Katherine of Aragon, Kipling argues that if 'Henry were to rank with the princes of Europe, his household would have to provide the plays, tournaments, pageantry, music, and entremets necessary to a Burgundian wedding celebration. ${ }^{53}$ Henry viII inherited his father's desire to display the magnificence of the Tudor regime, which he did most lavishly when he met Francis I between Guines and Ardres in 1520 on the Field of the Cloth of Gold. On this occasion, the two monarchs tried to outdo one another in spectacular (and enormously costly) events, which included pageants, jousts, and masques. In one of these, Henry appeared as Hercules leading nine other gentlemen playing the Nine Worthies. Such a performance was typical: whereas Henry vil usually remained a spectator of the festivities, Henry viII often took the lead in disguisings, masques, pageants, tilts, and other feats of arms. When Henry entertained the Imperial ambassadors in 1522, he and his company entered the lists carrying imprese of broken, wounded, and tormented hearts. In the masque and mock castle siege that followed, he played the part of Ardent Desire, dressed 'all in crimosin sattin with burnyng flames of gold' and led the assault, with oranges and dates as artillery, to liberate eight ladies, each representing a different allegorical virtue, from imprisonment in the castle of Lady Scorn. Of course he and his company won the day, freed the ladies, and 'daunced together verie pleasauntly. ${ }^{54}$ Similarly in 1524 , in a tiltyard device presented to the Scottish ambassadors who were in England attempting to negotiate the marriage of Princess Mary to James $v$ of Scotland, Henry and the duke of Suffolk entered disguised as old, silver-bearded knights. Having obtained permission to fight in the tournament from the queen, the lady privileged 
with the power over the tournament, the two 'old' knights threw off their disguises, revealed their identities, and ran eight courses at the tilt. The king in particular impressed the ambassadors with his strength and skill 'for thei saw his speres were broke with more force, then the other speres wer'. 55 The Elizabethan entertainments of the French ambassadors in 1564 and 1572 were direct descendants of such shows as these produced at the courts of Henry vir and Henry viII. As the Burgundian traditions drew on the literature of chivalric romance, so the debate between the two heralds in 1564, the one protesting against the ladies' refusal to accept the love offered them, the other objecting to the prosecution of 'love without liking', clearly situated the tourney within the context of a quest for love. The conflict between Desire and Chastity was a familiar one in the discourse of chivalric romance, a discourse that both England and France used in their self-representations. Besides suggesting how the masque and tourney engaged that particular motif in 1564, William Honing's account of the entertainment touches on other features of the shows that bespeak the magnificence and sophistication of Elizabeth's court: rich fabrics, exotic fashions, symbolic props, curious imprese, skilful dancing, and allegorical pageants. Presumably some of these aspects of the shows were included in the news dispatched to France, news that created there the reaction desired, for by 27 June, Sir Thomas Smith, the English ambassador in France, could report to Lord Burghley that 'De Gonnorre's entertainment is much praised here. ${ }^{56}$

Honing's letter, being a narrative report of the proceedings, offers only a glimpse of these elements that helped to create the impression that Elizabeth I kept a truly 'royal household'. ${ }^{57}$ To appreciate the production values of the entertainment, the details afforded by a revels account, such as that for the 1572 entertainment, are more helpful. On that occasion, when the duc de Montmorency came to England to explore the possibility of a marriage between Queen Elizabeth and the duc d'Alençon, the works office constructed a special banqueting house adjacent to Whitehall to accommodate the devices prepared for the ambassador and his retinue. For this free-standing structure, a linen draper, one Mistress Dane, provided over 1000 ells of canvas to cover the timber framework. Sixty-six plasterers fixed lath to the studs that supported the trussed roof. Thirty basket-makers made trellises of seasoned wicker and birch (180 loads) for the walls, and to the trellises 116 people wove ivy and bay, roses and other flowers. For the flowers, the revels office paid the wages of ' 214 . woorkfolkes the most of them being women that gathered bownde and sorted the flowers'. ${ }^{58}$ The floor was strewn with 
rose leaves 'pickt $\&$ sweetned with sweete waters'; 59 the pillars, frieze, and cornice gilded with gold and silver; and the roof beams adorned with painted pendants of the coats of arms of England and France, roses and fleur-delis. Rewards to those in the service industries went to messengers, carriers, boatmen, horse-coursers, guards 'for keeping the byrche from stealing', ${ }^{60}$ and victuallers, who provided the plasterers with bread and cheese on site because they 'wroughte all the nighte $\&$ mighte not be spared nor trusted to go abrode to supper'. The total cost of the banqueting house made in June? $£ 224$ 6s 10 d.

And then there were the costs of the 'triumph', that is, the pageants, masque, and fighting at the barriers; they amounted to another $£ 50611 \mathrm{~s}$ $8 \mathrm{~d}$. The production staff included thirty-six tailors working between seventeen-and-a-half and thirty days each; ten property-makers, embroiderers, and haberdashers working between eleven and twenty-four days; and a host of other artisans (joiners, a pattern maker, an upholsterer, a chandler, basket-makers, a coffer maker, wire-drawers, a buskin-maker, a feather-maker, and the suppliers of various goods). For the silk-weavers, William and Joan Bowll and Alice Montague, the show was a windfall; they were paid for their labour and stuff $£ 1617 \mathrm{~s} 81 / 2 \mathrm{~d}, £ 839 \mathrm{~s} 6 \mathrm{~d}$, and $£ 443 \mathrm{~s} 1 / 2 \mathrm{~d}$ respectively. They provided such things as gold fringe twisted; copper, silver, and silk buttons; bone lace with silver and spangles; Spanish silk of various colours; wigs, dressed and trimmed; crimson laces; ribbon of gold and silver; artificial flowers, bay leaves, and rose-headed nails. The materials and what they did with them offer glimpses of the aesthetics and the production values of the show. In some respects an extraordinary concern with symbolic details was evident: hence the buskins of cloth of gold for Alphonso Ferrabosco (who played Apollo to the ladies who represented the Muses), and 7s 8d spent on 'Curling of Heare made of Black silk for Discordes head'. ${ }^{61}$ A desire for literal brilliance was clear: hence the provision not only of candelabra, candles, and torches, but also of fabrics that would glitter in the light, such as the yards and yards of tinsel: thirty-four of blue and crimson, five of black, two of yellow, forty-one of white, ten of blue, twenty more of crimson, and seventy-seven more of blue and crimson. ${ }^{62}$ And visual splendour and variety were on display: hence the rich fabrics (silk, satin, taffeta, tissue), a spectrum of colours, a chain of gold leather, and the gilding of headpieces and set pieces. The rich, sensuous, intricate physical features of this entertainment aimed to impress upon the French not only the magnificence of Elizabeth's court but also England's high regard for France, for such splendid hospitality 
communicated how highly England prized the ambassadors and the regime they represented. Lord Hunsdon, leader of the English embassy that was in France at the same time seigneur de Gonnor was in England, felt very anxious about the importance of creating appropriate impressions. The specific issue for Hunsdon was the Garter he had and the chain he needed for presentation to the French king. Hunsdon complained to Lord Burghley that the Garter was too big for the king to wear and confessed that he would be ashamed to give the king any of the chains that he could afford to buy. So he asked Burghley 'to desire Her Majesty to consider these things, for they touch her honour more than any chain or garter or George is worth'. Then, alluding either to Sir Robert Dudley's own wealth or to the rich gifts the queen had given him, Hunsdon added, 'I assure you if I had such as Lord Robert hath, a should have one of mine'. 63

At the outset, I described the entertainments of the French ambassadors as 'occasional' and 'elite' drama. The former term applies because the timing of these shows at Elizabeth's court in 1564 and 1572 was determined by particular military events and their diplomatic consequences, specifically the treaties of Troyes and Blois. The plots and imagery of the theatrical devices represented, interpreted, celebrated, and were used to shape the future relationship between the two countries. The entertainments of foreign ambassadors were also 'elite' drama, even though, as the spending by the revels office in 1572 documents, many common people were indispensable to the productions. These people provided the stuff, skills, and labour without which the shows could not go on, let alone make manifest the magnificence of the court. Judging by William Honing's letter and Hall's Chronicle descriptions of entertainments for foreign ambassadors, however, the people crucial in the process of production had little or nothing to do as audiences with the finished products. The lavish display and the rarefied content of the shows also throw into relief the gap between the symbolic operations of the spectacle of power and the negotiations behind the scenes of specific political and economic issues. In 1564, seigneur de Gonnor's agenda included the release of French merchants arrested in Dover, the claim of the bishop of Coutances (his nephew Artus de Cossé-Brissac) to episcopal jurisdiction in the Channel Islands, and the relaxation of regulations limiting trade in wine, woad, and cloth directly with France. ${ }^{64}$ The liberalization of trade, advocated by the French ambassador and granted by Queen Elizabeth and the privy council, quickly affected merchants of London and led to the complaint of the 
Merchant Adventurers in August 1564 about the importation of cloth from the Low Countries on French ships. ${ }^{65}$

In contrast to more inclusive forms of entertainment such as civic receptions and manor house shows produced for royal progresses or lord mayor's shows that ambassadors often attended, ${ }^{66}$ the shows produced specifically for the entertainment of foreign embassies seem sealed off within a high culture that crossed national, but not class, boundaries. When Lord Hunsdon was in France in June 1564 to secure the ratification of the Treaty of Troyes and invest the French king with the Order of the Garter, he was entertained there as seigneur de Gonnor was in England. Hunsdon had an escort of highranking French courtiers, spent time hawking, dined with King Charles (he and the king alone at the table), heard the queen's ladies sing, saw the king and his sister dance, and received a gift of gilt plate worth between 500 and 600 marks. ${ }^{67}$ Despite these honours and gifts, some members of the court in England were, as the Spanish ambassador Guzman de Silva reported to the king of Spain in July, 'dissatisfied at the reception given in France to Hunsdon'. ${ }^{68}$ Hunsdon noted no masques or tiltyard devices comparable to those with which England entertained the French embassy, but a year later Pierre de Ronsard would dedicate to Queen Elizabeth and send to her his Elegies, Mascarades et Bergerie (1565), a book that contains almost all 'les Joustes, Tournoys, Combatz, Cartelz, \& Masquarades' ${ }^{69}$ presented in various places as commanded by Catherine de Médicis 'in her effort to bring together the warring factions among the princes of France..$^{70}$ Alluding at the very start of the volume to the Treaty of Troyes, Ronsard celebrates Elizabeth I both in the dedication and in the first poem in the collection, his 'Elegie à la Majesté de la Royne d'Angleterre', as a peace-making monarch. Although Hunsdon was not honoured with the performance of martial sports or masques during his ambassadorial visit to France, his sovereign received a published account of them. Ronsard's book of feats of arms and masques, which was also Catherine de Médicis's gift to Elizabeth I, acknowledged and endorsed, like the shows presented to seigneur de Gonnor at the English court, the end of discord between France and England and the achievement of peace. In these sixteenth-century entertainments for foreign ambassadors both in England and in France we may see courts communicating with other courts by means of a shared language of rich spectacle and dignified ceremony, a familiar set of dramatic and para-dramatic forms, and a shared literature of chivalric romance. 


\section{Notes}

I am grateful to Dr Sam Kinser for the opportunity to present an earlier version of this paper to the Seminar on Festive Culture at the Newberry Library; to St Jerome's University for the support necessary to work with the Thynne family papers at the Institute of Historical Research, London, and at Longleat; to the Marquess of Bath for permission to quote from the manuscripts; and to Dr Kate Harris, the archivist of Longleat, for help with the documents in her care.

1 Longleat: Thynne Household Papers, Volume 3, Correspondence 1558-73, ff 11819. Quotations from this manuscript are included by permission of the Marquess of Bath, Longleat House, Warminster, Wiltshire. All quotations not otherwise identified are from this manuscript.

2 David C. Price, Patrons and Musicians of the English Renaissance (Cambridge, 1981), 122.

3 Ibid, 129.

4 Ibid, 130.

5 Longleat: Thynne Household Papers, тн/Books/142 f 53; 152 f 32; 153 f 20; 159 f $10 ; 164$ f $18 ; 170$ f 50 .

6 Though not family papers, the Bulstrode Whitelock records that establish many of the performative details of James Shirley's masque, The Triumph of Peace (1633), illustrate the importance of Longleat holdings for our knowledge of drama at court. See Murray Lefkowitz, 'The Longleat Papers of Bulstrode Whitelocke: New Light on Shirley's Triumph of Peace', Journal of the American Musicological Society 18 (1965), 42-60.

7 Barrett L. Beer, 'Seymour, Edward, duke of Somerset (c.1500-1552)', Oxford Dictionary of National Biography (Oxford and New York, 2004-), doi:10.1093/ ref:odnb/25159. I am indebted to Beer throughout for this sketch of Seymour's rise and fall. Regarding the problematic nature of the charges brought against Somerset, see A.F. Pollard, England under Protector Somerset: An Essay (London, 1900), 292-9.

8 Mark Girouard, 'Thynne, Sir John (1512/13-1580)', Oxford Dictionary of National Biography (Oxford and New York, 2004-), doi:10.1093/ref:odnb/27421.

9 Sir John Thynne's eldest son and heir John, knighted by James I when he acceded in 1603, spent more of his time in London. This may account in part for the reduction in the early seventeenth century of the number of 'news letters' in the correspondence collection.

10 Mark Girouard, 'The Development of Longleat House between 1546 and 1572', Archaeological Journal 116 (1959), 203. 
11 Joseph Frank, The Beginnings of the English Newspaper 1620-1660 (Cambridge, 1961), 2. See also M.A. Shaaber, Some Forerunners of the Newspaper in England 1476-1622 (New York, 1966), especially 16-29 for news analogous to that in Honing's letter.

12 Longleat: Thynne Household Papers, Volume 1, Correspondence 1548-80, f 258.

13 Longleat: Thynne Household Papers, Volume 2, Correspondence 1542-57, f 213.

14 Longleat: Thynne Household Papers, Volume 3, Correspondence 1558-73, ff 67, 30, 183 and $177 \mathrm{v}$ respectively. William Streitberger describes a 'triumph' as 'a masquelike revel that combined dramatic action with martial combat' ("'Last of the Poore Flock of Hatfield”: Sir Thomas Benger's Biography', The Review of English Studies, ns 55 [2004], 676).

15 J.R. Dasent (ed.), Acts of the Privy Council of England 1542-1547 (London, 1890), 118.

16 Jacqueline D. Vaughan, 'Secretaries, Statesmen and Spies: The Clerks of the Tudor Privy Council, c. 1540-c. 1603', PhD thesis (University of St. Andrews, 2006), 24.

17 James Gairdner and R.H. Brodie (eds), Letters and Papers, Foreign and Domestic, Henry VIII, 21 vols (London, 1898), 16.1308 (item 28).

18 R. Lemon (ed.), Calendar of State Papers, Domestic Series, of the Reigns of Edward VI, Mary, Elizabeth 1547-1603 (London, 1856), 90 (item 7).

19 Vaughan, 'Secretaries, Statesmen and Spies', 47.

20 Surrey History Centre, Woking: Loseley Papers Z/407/Lb 368 (25 March 1543).

21 See Albert Feuillerat (ed.), Documents Relating to the Office of the Revels in the Time of Queen Elizabeth (Louvain, 1908), 60-2, who also notes other potentially relevant records of a 'Willelmus Huninge, clericus consilij', 'Honnynges seruante', and 'mistress Honnyng seruaunte' (48n14).

22 The two parts of the letter may have been written at different times. When Honing turns his attention to the journey from Dover to London, he begins with the commendations to Sir John Thynne and his wife that normally appear at the start of a letter. The pen, ink, and handwriting also change at this point, so that a reasonably clear secretary hand gives way to a much less legible one.

23 Lemon (ed.), CSP Domestic, 240-1 (items 8, 9, 10, 11, 17).

24 Ibid, 241 (item 28), for a letter from the council to the sheriff of Kent in which the council complains about the poor attendance of gentlemen of the county in receiving the ambassador and orders him to ensure a better showing when the ambassador returns for his departure to France.

25 John Bruce and Thomas Thomason Perowne (eds), Correspondence of Matthew Parker (Cambridge, 1853), 214-15.

26 Ibid, 215. 
27 Ibid, 216.

28 R.B. Wernham, The Making of Elizabethan Foreign Policy, 1558-1603 (Berkeley, Los Angeles, and London, 1980), 26-8. See also John Guy, Tudor England (Oxford, 1988), 226-8, and Susan Brigden, New World, Lost Worlds: The Rule of the Tudors 1485-1603 (New York, 2000), 213-23.

29 T.A. Morris, Europe and England in the Sixteenth Century (London and New York, 1998), 326-7.

30 J.H.M. Salmon, Society in Crisis: France in the Sixteenth Century (New York, 1975), $147-8$.

31 Simon Adams, 'Dudley, Ambrose, earl of Warwick (c.1530-1590)', Oxford Dictionary of National Biography (Oxford and New York, 2004-), doi:10.1093/ref:odnb/8143. See also Wallace T. MacCaffrey, 'The Newhaven Expedition, 1562-1563', The Historical Journal 40 (1997), 19-21.

32 Roman D’Amat (ed.), Dictionnaire de Biographie Française (Paris, 1961). Charles de Cossé was also the older brother of Artus, seigneur de Gonnor, leader of the French embassy to England.

33 John Nichols, The Progresses and Public Processions of Queen Elizabeth, 3 vols (London, 1823), 1.148. See also Paul L. Hughes and James F. Larkin (eds), 'Announcing Peace with France', Tudor Royal Proclamations, Vol. II: The Later Tudors (1553-1587) (New Haven and London, 1969), 249-50.

34 Feuillerat (ed.), Documents Relating to the Office of the Revels, 116.

35 Ibid, 447n116 (25).

36 Joseph Stevenson (ed.), Calendar of State Papers, Foreign Series, of the Reign of Elizabeth 1564-5 (London, 1870), 156-7.

37 For the deliberate provision of a privileged viewing place for the monarch, see Siobhan Keenan, 'Spectator and Spectacle: Royal Entertainments at the Universities in the 1560s', Jayne Elisabeth Archer, Elizabeth Goldring, and Sarah Knight (eds), The Progresses, Pageants, and Entertainments of Queen Elizabeth I (Oxford, 2007), $86-103$.

38 These participants were probably Charles Howard (1536-1624) and William Howard (c.1540-1600), sons of William, Baron Howard of Effingham. The former answered the challenge (from Sir George Howard among others) to a tourney on 1 January 1559 and later fought in tournaments in 1571 and 1572. The latter participated either in the tournament held on 5 November 1559 or in that April 1560; he also answered the challenge in 1571. See Sydney Anglo, 'Archives of the English Tournament: Score Cheques and Lists', Journal of the Society of Archivists 2 (1962), 160-1 and Alan Young, Tudor and Jacobean Tournaments (London, 1987), 125-7. Honing also mentions that in 1564 Sir Henry Sidney, Sir Francis Knollys, Sir Henry 
Lee, Mr Garret, Mr Markham, George Wiseman, and Thomas Cornwallis took part in the running at the ring and John Astley, master of the jewel house, served as a marshall.

39 Erzsébet Stróbl, 'The Figure of the Wild Man in the Entertainments of Elizabeth I', Zsolt Almasi and Mike Pincombe (eds), Writing the Other: Humanism versus Barbarism in Tudor England (Newcastle upon Tyne, 2008), 71.

40 The 1515 show is in Edward Hall, Hall's Chronicle; containing the History of England, during the Reign of Henry the Fourth and the Succeeding Monarchs, to the End of the Reign of Henry the Eighth (1809; New York, 1965), 580. Dorothy Yamamoto, The Boundaries of the Human in Medieval English Literature (Oxford, 2000), 174-6, and Richard Bernheimer, Wild Men in the Middle Ages: A Study in Art, Sentiment, and Demonology (New York, 1970), 65 and fig. 11, provide evidence of wild men acting as knights rather than as embodiments of 'the uncourtly other'.

41 See also Lisa Hopkins, Queen Elizabeth I and Her Court (London, 1990), 158: 'the staging of a tournament in an ambassador's honour was a sign of how important the Queen thought he was and how much she valued his country's friendship, but they also provided a discreet reminder that if a foreign country ever did think of war, then England was full of brave young men who would be able to put up a very good fight indeed'.

42 See Thomas M. Greene, Besieging the Castle of Ladies, Center for Medieval \& Early Renaissance Studies, Occasional Papers 4 (Binghamton, 1995), 1-39, for analogues to this form of martial sport. Regarding the use of the literature of chivalric romance in Elizabethan tournaments, see Frances A. Yates, Astraea: The Imperial Theme in the Sixteenth Century (London and Boston, 1975), 88-111; Roy Strong, The Cult of Elizabeth: Elizabethan Portraiture and Pageantry (Berkeley and Los Angeles, 1977), 139-62; and Jean Wilson, Entertainments for Elizabeth I (Woodbridge, 1980), 2638.

43 See Young, Tournaments, figs 15, 38, and 40 for contemporary illustrations of fighting with swords and staves at the barriers.

44 Sarah Carpenter, 'Performing Diplomacies: The 1560s Court Entertainments of Mary Queen of Scots', The Scottish Historical Review 82 (2003), 194.

45 Frederick Gard Fleay, A Chronicle History of the London Stage 1559-1642 (London, 1890), 19, first suggested this possibility. For the projected Nottingham Castle devices, see E.K. Chambers and W.W. Greg (eds), 'Dramatic Records from the Lansdowne Manuscripts', Malone Society Collections 1:2 (1908), 143-8.

46 Central Library, Bradford, West Yorkshire, ms: Hopkinson xv, ff 32-3.

47 Carpenter, 'Performing Diplomacies', 194-225. 
48 Susan Doran, Monarchy and Matrimony: The Courtships of Elizabeth I (London and New York, 1996), 57. The contemporary account of this entertainment at the Inner Temple, which Dudley later took to court, is that of Gerard Legh, The Accedens of Armory (London, 1562), 202-27. An edition of Legh's work appears in Alan H. Nelson and John R. Elliott Jr (eds), REED: Inns of Court (Cambridge, 2011), 363-79. See also D.S. Bland, 'Arthur Broke's Masque of Beauty and Desire: A Reconstruction', Research Opportunities in Renaissance Drama 19 (1976), 49-55; Marie Axton, The Queen's Two Bodies: Drama and the Elizabethan Succession (London, 1977), 39-48 and her 'Robert Dudley and the Inner Temple Revels', The Historical Review 13 (1970), 365-78; and Clare Rider, 'Lord Robert Dudley: "Chief Patron and Defender” of the Inner Temple', Inner Temple Yearbook (2004-5), 48-52.

49 Gabriel Heaton, Writing and Reading Royal Entertainments: From George Gascoigne to Ben Jonson (Oxford, 2010), 50. For Dudley's reliance on chivalric entertainments and martial sports in his wooing of the queen and the advancement of his political agenda, see Richard C. McCoy, 'From the Tower to the Tiltyard: Robert Dudley's Return to Glory', The Historical Journal 27 (1984), 425-35 and The Rites of Knighthood: The Literature and Politics of Elizabethan Chivalry (Berkeley and Los Angeles, 1989), 28-54.

50 He had certainly impressed Catherine de Médicis and others in France; hence, Ronsard's representation of Dudley in 1565 as a complete gentleman. See Pierre de Ronsard, 'Elegie à Mylord Robert Du-dlé Conte de L'Encestre', Paul Laumonier (ed.), Oeuvres Complètes, 17 vols (Paris, 1948), 13.63-74.

51 Doran, Monarchy and Matrimony, 40-72.

52 The Triumph of Honour: Burgundian Origins of the Elizabethan Renaissance (The Hague, 1977), 2.

53 Ibid, 9.

54 Hall, Chronicle, 631.

55 Ibid, 689.

56 Stevenson (ed.), CSP Foreign, 167. Similar concern that news of ambassadorial entertainments should make a good impression abroad was also registered in 1572 . In a letter to Lord Burghley the earl of Lincoln reported almost immediately after Elizabeth's reception of Montmorency that there 'hathe ben great mislykinge taken against suche as showld have gyven knowledge hyther' of 'the receyvinge of Monsieur Momerancie in England' (Nichols, Progresses, 302n).

57 Hall, Chronicle, 690; the phrase is that of the Scottish ambassadors who were entertained by Henry viII during the Christmas season 1524-5 with banqueting, feats of arms, masques, and a projected castle siege. The ambassadors were surprised that 
during a time of war the English court would indulge in such lavish, costly merriment; that is, that Henry vin would keep such a 'royal household'.

58 Feuillerat (ed.), Documents Relating to the Office of the Revels, 164.

59 Ibid, 163.

60 Ibid, 166.

61 Ibid, 159.

62 On this aspect of the visual spectacle of such shows, see Barbara Ravelhofer, The Early Stuart Masque: Dance, Costume, and Music (Oxford, 2006), 157-69.

63 Stevenson (ed.), CsP Foreign, 157.

64 Concerning the bishop of Coutances's claim, see C.S.L. Davies, 'International Politics and the Establishment of Presbyterianism in the Channel Islands: The Coutances Connection', Journal of Ecclesiastical History 50 (1999), 498-522. Concerning the other two issues, see R. Lemon (ed.), CSP Domestic, 241-4 passim and Stevenson (ed.), CSP Foreign, 159 and 162.

65 Lemon (ed.), CsP Domestic, 243 (item 50).

66 See Alexandra F. Johnston and Margaret Rogerson (eds), REED: York (Toronto, 1979), 1.154-5; R.W. Ingram (ed.), REED: Coventry (Toronto, 1981), 130-1; and Robert Laneham, A Letter, ed. R.J.P. Kuin (Leiden, 1983), 52. These receptions illustrate common people presenting their local customary drama.

67 Stevenson (ed.), CSP Foreign, 165-7 (items 522 and 523).

68 Martin A.S. Hume (ed.), Calendar of Letters and State Papers Relating to English Affairs, Preserved Principally in the Archives of the Simancas. Vol. I. Elizabeth. 15581567 (London, 1894), 370.

69 Ronsard, Oeuvres Complètes, 13.36.

70 Maureen Quilligan, 'When Women Ruled the World: The Glorious Sixteenth Century', Early Modern Culture: An Electronic Seminar 5 (2006), par 6. 